\title{
GCU
}

Glasgow Caledonian

University

University for the Common Good

\section{Action research and participatory democracy in social enterprise}

Gleerup, Janne; Hulgard, Lars; Teasdale, Simon

Published in:

Social Enterprise Journal

DOI:

10.1108/SEJ-02-2019-0012

Publication date:

2019

Document Version

Author accepted manuscript

Link to publication in ResearchOnline

Citation for published version (Harvard):

Gleerup, J, Hulgard, L \& Teasdale, S 2019, 'Action research and participatory democracy in social enterprise', Social Enterprise Journal. https://doi.org/10.1108/SEJ-02-2019-0012

\section{General rights}

Copyright and moral rights for the publications made accessible in the public portal are retained by the authors and/or other copyright owners and it is a condition of accessing publications that users recognise and abide by the legal requirements associated with these rights.

Take down policy

If you believe that this document breaches copyright please view our takedown policy at https://edshare.gcu.ac.uk/id/eprint/5179 for details of how to contact us. 


\title{
Action Research and Participatory Democracy in Social Enterprise
}

Janne Gleerup, Associate professor, Roskilde University, Denmark.

Lars Hulgård, Professor Roskilde University, Denmark and University College of Southeast

Norway, Norway, hulg@ruc.dk.

Simon Teasdale, Professor of Public Policy and Organisations, Glasgow Caledonian University,

UK, simon.teasdale@gcu.ac.uk

This is the author accepted version of a paper to be published in Social Enterprise Journal. Please cite as: Gleerup, J., Hulgård, L., and Teasdale, S. (2019 forthcoming). Action Research and Participatory Democracy in Social Enterprise, Social Enterprise Journal.

Keywords Action Research, social enterprise, normativity, participatory democracy

\begin{abstract}
Purpose: The purpose of this article is to introduce the reader to the Nordic tradition of Critical Utopian Action Research (CUAR) and to demonstrate how CUAR might reinvigorate participatory democracy as an intrinsic characteristic of social enterprise. This leads us to sketch out the beginnings of how researchers might work with communities to help realise their democratic impulses through social enterprise.

Design / methodology: This article aims to synthesise Participatory Action Research literature, particularly CUAR, with literature on social enterprise and democracy to demonstrate how the two approaches might fruitfully be combined.

Findings: We show how CUAR might be utilised by researchers, to articulate new social enterprise organizational responses to local problems; or to reinvigorate democracy within existing social enterprises.

Originality / Value: This exploratory work marks (we believe) the first attempt to bring together social enterprise and CUAR.
\end{abstract}




\section{Action Research and Participatory Democracy in Social Enterprise}

\section{Introduction}

When the international research network EMES observed the emergence of social enterprise (SE) in the mid-1990s, they argued that such enterprises were characterized by three inter-related dimensions: social, economic and democratic, and that they drew resources from each of these dimensions (Borzaga and Defourny, 2001). Theoretically this implied that SEs embedded the Polanyian poles of reciprocity, redistribution and market exchange for the wider benefit of communities (Borzaga and Defourny, 2001). The wider policy community saw SE as offering more than just a practical organisational alternative to 'free' market liberalism and state socialism. As the former president of the European Commission dwelled upon their ability to demonstrate "the spirit of solidarity" and have "an entrepreneurial outlook", he also emphasized the importance of organizations in the social economy as "schools of democratic participation and active citizenship" (Prodi, 2002). This recognition of SEs as organizations that had a positive economic, social and democratic impact laid the foreground for the emergence of SEs as a policy instrument across much of Europe over the subsequent 20 years. However, as SE entered the mainstream its critical potential was diminished. Within academia, scholars have tended to focus narrowly on the ways in which entrepreneurial forms and approaches might be extended to 'solve' social problems (Dart, 2004). The neglect of the participatory dimension, combined with a focus on heroic individuals such as Muhammad Yunus, Bill Drayton and the institutions (such as Skoll and Ashoka) that support them, has produced a selective view of what is good for society (Dey and Steyaert, 2012).

In the 'real world', as diverse groups competed for the resources attached to SE development, its meaning was diluted to the extent that any commercial organization which also pursued a social mission might be labelled a SE (Teasdale 2012). Policy definitions and legal forms accordingly moved away from the original SE ethos. New legal forms for SEs in countries such as the United Kingdom, South Korea, and United States had no legal requirement for democratic engagement of members (Bidet and Hum, 2011; Galera and Borzaga 2009; Smith and Teasdale, 
2012; Young and Kim, 2015). In Italy new SE laws focused on the social and entrepreneurial dimensions while totally neglecting the democratic dimension (Calo and Teasdale, 2016). New forms of social business have no requirement for the participation of members in their governance (Defourny and Nyssens 2016; Teasdale, 2012). Hence today, the democratic dimension of SE has disappeared while the entrepreneurial dimension is (over) emphasized by politicians, policy makers and social entrepreneurs themselves (Pestoff \& Hulgård, 2016). Rather than being seen as a way of filling the democratic void left by the withdrawal of the state, SE is increasingly seen by more critical scholars as contributing to that democratic void through the introduction of market principles to civil society (Eikenberry, 2009).

As researchers, this scenario presents us with three broad options. First, and most commonly, we might observe that academic and policy concepts interact with each other and change over time (Giddens, 2013). Our job is to work with current conceptualisations. If participatory governance is no longer a feature of SE, then our conceptual frameworks need to adapt accordingly. Alternatively, we might study why participatory governance has become detached from contemporary meanings of SE. Here the work of Dey and Steyaert (2012) on discourse as a mechanism used by those in power to convey what 'should be' rather than 'what is' offers considerable potential. Finally, we might heed recent pleas to reintroduce participatory democracy to the practice of SE (Kay, Roy and Donaldson; 2012; Eikenberry, 2009). This explicitly normative approach involves abandoning the illusionary stance of detached observer and seeking to work with practitioners to reintroduce participatory governance to SE. This necessitates our understanding the challenges and complexities and tensions that participatory governance brings about, particularly when (re)introduced into organizations with social and commercial logics that might be more immediately served through hierarchical decision-making structures (Dey and Steyaert, 2012). It is this third approach we seek to expand in this article, through an exploration of how the dimension of participatory governance in SE may gain from the Nordic tradition of Critical Utopian Action Research (CUAR). This leads us to sketch out the beginnings of how researchers might work with communities to help realise their democratic impulses through social enterprise. 
The paper proceeds as follows. First, we outline various dimensions of participation in SE. We do this with reference to the EMES approach to SE (Nyssens, 2006; Borzaga \& Galera, 2013; Hulgård \& Spear, 2006; Pestoff, 2014; Pestoff \& Hulgård, 2016) and contemporary developments in Europe (European Commission, 2014), and particularly Denmark showing how this participatory dimension has been neglected, and what the democratic implications of such neglect might be. Secondly, we introduce the reader to the key components of Action Research before honing on the Nordic tradition of Critical Utopian Action Research (CUAR), which, as we explain, appears well-suited to reinvigorating a debate around democratic participation, not just within the SE but also at a societal level. This invites a wider discussion about how the adoption of theoretical understandings and practical methods from Action Research into the field of SE can strengthen the political dimension of SE both at practical and at scholarly levels (Egmose, 2015). The aim of our paper therefore, is to facilitate this rare cross-disciplinary dialogue between SE and CUAR, in order to stimulate the sociological imagination in ways that can qualify further exploration.

\section{The EMES definition of social enterprise}

In one of its first research projects, "the Emergence of Social Enterprises in Europe" (EMES) the EMES European Research Network identified an evolution among organizations inside the third sector towards a more entrepreneurial and productive dimension. To capture this evolution, EMES proposed and "tested" a definition of SE. The EMES approach to SE highlights that the social, the economic and the political dimensions together distinguish this type of entrepreneurial activity from other forms of enterprise (Defourny, Hulgård \& Pestoff, 2014; Nyssens, 2006; Borzaga \& Defourny, 2001).

As a part of this first research project an ideal type of SE was formulated, and this was applied both to the comparative study of emerging SEss in Europe (1996-1999) and a comparative study of 165 Work Integration Social Enterprises across Europe (2001-2004). This definition consists of three sets of criteria, which together form an ideal type or a working hypothesis. Together the three sets comprise nine criteria (see Table 1) which encompass the 
economic, the social and the governance dimensions of SE (Borzaga and Defourny, 2001; Nyssens, 2006 ; Hulgård, 2011).

\section{TABLE 1 HERE}

\begin{tabular}{|l|}
\hline \multicolumn{1}{|c|}{ Table 1: EMES definition of social enterprise } \\
\hline Three Economic criteria \\
- A continuous activity producing goods and/or services \\
- A significant level of economic risk \\
- A minimum amount of paid work (not only volunteers) \\
\hline Three Social criteria \\
- An explicit aim to benefit the community \\
- An initiative launched by a group of citizens \\
- A decision-making power not based on capital ownership \\
- A A higee Governance criteria \\
- A participatory nature, which involves the persons affected by the activity
\end{tabular}

This EMES definition has had significant impact both on other researchers focusing on the third sector, social economy and social entrepreneurship (see for example, Kerlin, 2009) and the development of legal frameworks and policies.

Since the beginning of the $21^{\text {st }}$ century governments, interest organizations and supra national organizations have been concerned with how to regulate the social economy through legal frameworks and policies that encourage the growth of SEs (Andersen and Hulgård, 2016). Alongside the introduction of new legal forms such as the British Community Interest Company and the Italian Social Cooperative, policymakers at national and European levels have begun designing regulatory frameworks to stimulate the so-called SE-ecosystem (European Commission, 2015; Hazenberg et al. 2016). The implementation of legal frameworks and institutional support 
structures (ecosystems) targeting the entire SE field is not unanimously welcomed. Policymakers have considerable power to push the field in particular directions, disrupting the fragile equilibrium that may have built up over time. In some cases, policy action can push the entire field in the direction of a mainstream market economy, for example in the United Kingdom which has become characterized by franchise models, incubator mechanisms, the pursuit of scale and managerial procedures originating in the 'capitalist firm' (Steiner and Teasdale, 2016). In a different world such policies might have been directed towards enhancing the capacities of a more participatory social economy, supporting SEs with a close connection to social movements and solidarity enterprises (Coraggio et al, 2015: 239), the cooperative tradition (Hulgård and Bisballe, 2008) or an alternative economy sector (Castells et al, 2012: 9).

One example may serve as an illustration as to how high-level decisions potentially shape the future of the social economy. In February 2013, the Danish government formed the Committee for Social Enterprise with 15 experts and representatives from ministries and interest organizations. The task was to identify (within six months) barriers faced by SEs, and to propose a framework for an institutional support structure (education, training, finance.) and a new law on SE. A fast and smooth collaboration in the committee and later in the Danish parliament led to the adoption of a new law in June 2014. To some degree, this new law on "Registered Social Enterprises" follows the line of thought suggested by the EMES network insofar as it covers all of the three sets of criteria, economic, social and governance. According to the Danish law, SEs can register as such if they are independent of public authorities, are operating with an explicit social purpose, reinvest the profit and are participatory, transparent and responsible in their governance. However, the notion of participatory governance is weakened, in the sense that the law simply states that for a SE to be registered it "must be involving/inclusive and responsible in its functioning" (Law no. 711, 2014: §5.4).

\section{The loss of participatory democracy as a cornerstone in social enterprise}

There are indications that SE today is less valued for its ability to combine social, economic and democratic potential (Coraggio et al, 2015; Laville et al, 2015) than the ability to contribute towards 
narrower economic goals such as the work integration of marginalized people into the conventional market economy. But this is an activity that could conceivably be done by organizations in any sector of the economy. As we have already argued, it is the democratic dimension that separates a SE from a conventional private enterprise, through its capacity to enhance participatory governance and democracy.

Sadly, it appears there is a lack of real interest in participatory governance and democracy among those parliaments, governments and public authorities that are increasingly adopting legal frameworks and 'eco-systems' for SE (European Commission, 2014). In a preliminary mapping-exercise of SEs and their eco-systems in Europe executed by researchers on behalf of the European Commission, SEs were characterized by the "three key dimensions" outlined by the EMES network: "Governance, thus, distinguishes social enterprises even more sharply from mainstream enterprises and traditional non-profit organizations" (European Commission, 2014: v). However, when it comes to the eco-system, the SE support system, and social entrepreneurs themselves, the governance dimension is of minor relevance, if not absent. Out of twenty-nine European countries studied for the mapping report, in at least fifteen countries, "governance is not seen as a defining characteristic of social enterprise" (European Commission, 2014: iv).

This is not simply a policy or academic exercise that has no relevance to the real world. Recently the leader of a Danish SE umbrella organization argued, that: "Today social enterprises are often thought of as experiments or projects and almost in opposition to capitalism, but I believe that the future is to think social and commercial at the same time. The renewal of social enterprises within this organization will combine social results with "hardcore economythinking” (http://www.tuborgfondet.dk/nyhed/settlementet-lancering). At a visit for SE stakeholders in May 2017 attended by one of the authors, the same leader said that employees in the SE are encouraged to be "commercial in front of the desk when dealing with customers and social behind the desk when interacting among themselves".

The implication here was that 'old school' SEs may have been socially responsible but commercially inefficient, and that new SEs need to become more business-focused. 
A similar point is made by scholars, originally in distinguishing between 'democratic' European social enterprises, and initiatives in the United States created by individuals to create social value, but without any formal democratic requirements (see Defourny and Nyssens, 2014). More recently it might be said that while the 'participatory element of social enterprise has faded away at the organizational level, as newly formed 'social businesses' in Europe bear more resemblance to their American cousins than 'old-school' SEs emanating from the co-operative tradition (Teasdale, 2012; Defourny and Nyssens ,2016). There has been a gradual move away from SEs related closely to social movements and / or community-oriented activists to those adopting mainstream market behaviour. This mirrors developments across civil society. Whereas the hybridity of civil society in the twentieth century has been portrayed as 'half movement, half government', more recent developments can be understood as a drive towards organizational solutions of 'half charity, half business' (Wijkström, 2011: 46). The threat of such a move to both participatory and deliberative democracy has been touched upon in the academic literature (Eikenberry, 2018; Ruebottom, 2018). Eikenberry (2009) calls upon scholars to work with practitioner groups to re-embed democracy within civil society.

In the next section of this article we will explore if an action research approach could form part of a movement aimed at reinforcing the democratic, participatory and inclusive characteristics of SE that were so important during its emergence. Accordingly, we adopt an explicitly normative approach in line with the critical theory tradition, in the sense that we sympathize with the potential of SE to become a non-capitalist economic agent of social change.

\section{Social Enterprise from the perspective of Action Research}

Action Research is a tradition embedded in the aim to integrate research and social change. The founder was the social-psychologist Kurt Lewin, who named the tradition back in the middle of the Twentieth Century. Action Research has since then developed in many directions, while maintaining an interest in exploring how research can engage directly in processes of change (Reason and Bradbury, 2001). To different degrees - depending on the specific tradition - Action Research is informed by a critical normative aim to contribute to democratic development of society 
through empowering people to take part in the discussions and decision-making processes that surround and determine their lives. Knowledge production must strive to understand what characterizes the problems studied, but Action Research also aims to use this knowledge for practical purposes within the organization being 'researched'. Methodologically, project designs are based on a 'joint venture' between researchers and practitioners cooperating around experiments based on shared interests. Hence, an Action Research design combines descriptive and proactive components. Research questions aim to engage analysis in the double sense of 'understanding' and 'changing' in a process where theoretical research knowledge and practical everyday life experience come together (Greenwood and Levin, 2007).

In Action research, the researcher moves from the role of the spectator to the role of participant. The tradition thus rejects as an illusion the traditional positivist understanding of the researcher as a neutral observer of reality. Human beings are - to some extent unconsciously always deeply embedded in the object studied. Rather than try to escape this, research must find ways to deal with this precondition in a responsible and reflexive way.

The Nordic philosopher and action researcher Skjervheim explored the researcher's role from an ontological and epistemological perspective. He points out that: 'We cannot choose commitment - as human beings in the real world we are committed' (Skjervheim, 1996). What we can choose however, is how to make use of the engagement. This understanding is ontologically rooted in the tradition of philosophical hermeneutics by Gadamer who argues, that the process of identity- and sense making is social and consists of an ongoing process of interpretation. Critical Utopian Action Research (CUAR) is inspired by this position and adds inspiration from the German critical theorist Oskar Negt who focuses on the formation of experience and the importance of creating arenas for collective learning and collective interpretation of everyday life experiences (Negt 1985, 1994) ${ }^{1}$. Such arenas for social learning are important to establish, if the aim is to

\footnotetext{
${ }^{1}$ Negt has in many ways inspired the Danish tradition of Action Research as well as other theoretical and empirical traditions of research, e.g. within the areas of educational studies, work-life studies and studies on the role of media in the public sphere. (Olesen et al. 1997).
} 
empower people to engage and take responsibility in their own lives - maybe in the role of influential participants in a SE. We return to the question of how to establish such learning arenas at the end of this paper.

In Denmark and other Nordic countries, Action Research traditions have inspired labour market studies, work-life studies and educational studies since the early 1980s (Weber, Nielsen and Olesen, 1997). During the last decade, the methodological toolboxes of Action Research have been adapted towards the development of modernization and competence development policies in the public sector, sometimes translated into strategies of Action Learning or fused with strategies of organisational development (Gleerup and Nielsen, 2014). The rediscovery of Action Research is partly due to a focus on how to make use of practical, local knowledge in processes of change - based on the engagement and commitment among participants often the employees within the workforce.

However, as we have seen in the development of SE, the dimension of participation can be weakened, or even washed away, when Action Research strategies and developmental methods are chosen only because of their sensibility towards practice and capability to engage people. If methods are instrumentalised and emptied of democratic ambition the efforts can legitimize hidden managerial desires of recalibrating orientations and values among the employees in undemocratic or even manipulating ways (Gleerup 2010).

To protect against this, a radical variant of Action Research; the tradition of Critical Utopian Action Research (CUAR) (Nielsen 2005, 2006), explicitly emphasises both local participation and democratization at societal level within the theoretical framework and practical designs for processes of change. The CUAR tradition stresses the moral responsibility of research which is always - directly or indirectly - full of political implications. The CUAR tradition engages in debates on how research can be brought into practical use in ways that support social inclusion, and give equal voice and value to the practical experiences of less powerful groups. CUAR thus 
seems well placed to re-embed the democratic cornerstone of SE. While CUAR is not a shortcut, or even practical guide, to the democratization of workplaces or society, we hope that introducing readers of this journal to a novel approach to the facilitation of democratic inclusion as a process of collective learning might stimulate reflection on how to engage with $\mathrm{SE}(\mathrm{s})$ as a way of instigating, as well as researching, social change.

\section{CUAR - theoretical point of departure}

CUAR is inspired by the German tradition of Critical Theory combining structural (marxist) analysis approaches with the socio-psycho-analytical tradition of understanding the subjective (Becker-Schmidt 1982). It is oriented towards emancipation, leaning and empowerment as stepping stones in societal democratization. The critical utopian dimension differentiates the tradition from other Action Research positions by striving towards exploring both the most critical aspects of our lives and our (latent) utopian longings for a better and more meaningful life. The keywords critical and utopian mark poles in a dialectic tension. When understanding interaction between societal and subjective logics as a dialectic process, the aim is to avoid reductionist approaches that tend to understand subjective experience as a mirror of objective conditions. The subjective experience is always more than that, and the patterns within the dialectic interaction between micro macro levels are difficult to grasp, if operating from one perspective only. This is why Action Research approaches are often combined with other approaches to ensure a multidisciplinary openness relevant to the specific research question.

\section{Why and how the aim of democratisation?}

One of the founders of CUAR, the Danish Professor Emeritus Birger Steen Nielsen, refers to Kurt Lewin and Paolo Freire as sources of inspiration when he describes the concept of democracy. In a recent publication Nielsen states: "Democracy is not just a dimension of societal transformation, but it's very meaning, not just a goal for our transformational aspirations but the way itself through which this transformation can take place. Democracy is the name for citizens' self-regulation and cultivation of their common life conditions. In this sense, it is of course certainly also a way of deciding - in freedom, by yourself together with your fellow citizens when it comes to common 
affairs. Of course, such kind of decision-making must be related to different forms and levels of societal institutions that, however, and this is a crucial point, to a great extent will have to be (re)invented" (Nielsen and Nielsen, 2016:77).

Nielsen and Nielsen here stress that this definition of democracy is different from the capitalist market logic. It seeks to open other understandings of the public, and of citizens as more than just voters spectating upon democracy. In the widest ambition, this idea of democracy also challenges structural forms of dominance in society through experimenting with learning strategies to improve the influence and autonomy of what we might call "ordinary people" in relation to their everyday life conditions.

Integrating research and everyday life experience - democratization of knowledge production The democratic goal in Action Research is not confined to enlarging the sphere of participation as a route to democratization. Action research in general, and CUAR in particular, also emphasise the need for the democratization of knowledge production. This is in line with critical and peoplecentred approaches to social innovation (Moulaert et al. 2013; Hulgård and Shajahan, 2013). Action Research projects unite theory and practice, meaning that theoretical or scientific knowledge is brought into a dialogue with practical everyday life knowledge in the research design. Both kinds of knowledge must inform the process of change and they are not understood as oppositional but mutually qualifying. Hence, the research questions are formulated through cooperation between researchers and practitioners wanting to create some kind of change.

In Action Research, the concept of knowledge stresses the local and contextual component. In the research design, the ambition is to establish work and learning communities where different forms of knowledge are equated and expert knowledge serves the goals of change formulated by the practitioners of the project. Through a pedagogical design for working with analysis of practical experience within a collective workshop framework, the social and general dimensions of local knowledge production can be identified.

\section{CUAR - the methodological toolbox of learning and changing}


The CUAR tradition is also inspired by the German-Austrian writer and grassroots activist Robert Jungk who invented the so-called Future Creating Workshop (Jungk and Mûllert, 1984). The workshop is organised in ways that encourage both critical reflection and social imagination pointing into the future. A core principle of the workshop is that everyday life experiences and utopian thinking are important components when facilitating spaces of social learning and renewing of our society in a democratic way. A famous quote by Jungk states that

"The future is too important to let experts be in charge of". Although not saying that we do not need experts altogether, we also need practical experience, emotions, intuition and aspirations as important sources of renewal. Nielsen and Nielsen have designed a follow up to the future creating workshop called the Research Workshop. Here, subject experts are invited to help practitioners develop strategies of change in qualified ways. The combination of the two workshops opens up a multitude of angles to view the world from, aiming to provide a broad point of departure for discovering the complexity of dimensions in our common affairs. Finally, we need to bear in mind, that a variety of different futures are thinkable and possible. This strong combined emphasis on critical analysis and the pursuit of utopian aspirations in the creation of alternative futures differentiates CUAR from other Action Research traditions, which focus more pragmatically on involving practitioners in problem solving activities.

In the following section, we will briefly summarise the idea and content of the Future Creating Workshop before ending the paper by asking if this practical tool, along with the basic anticipations behind the tradition of CUAR may inspire the rehabilitating of participation and democratization components of SE.

\section{The Future Creating Workshop - a democratic method of change}

The Future Creating Workshop (FCW) is used in Action Research projects where practitioners have decided to initiate a process of change and require inspiration to start the process. If possible, the workshop takes place over two days, but it is possible to do in one day. The theme of the workshop is formulated in cooperation between practitioners and researchers, but the core ambition must derive from practice. The workshop contains three phases: critique, utopia and realization. In the 
phase of critique, participants brainstorm over all kinds of problems related to the theme.

Everything is stated in keywords on a wall of paper. All kinds of critiques are legitimate; critiques are not discussed - just put up on the wall. After the brainstorming all participants vote for the three most important critiques. The 'winning' critiques are themed and participants form groups to discuss and interpret these theme before performing a wordless presentation of the problem to the other participants. After a short break the phase of utopia begins. The participants are now invited to imagine a situation where literally everything is possible. They are encouraged to bring up ideas of how the ideal future would look. As in the first phase the participants brainstorm, vote and present creative images of the utopian ideas. In groups participants subsequently work to realise the potential of these utopian ideas. In the third phase participants again work with the utopian ideas, but with respect to real world conditions. The point of departure in this phase is: We will not leave our utopian ideas out of sight - how can be begin a process of realization in the real world? The participants group and work with plans for realization of elements from the utopian goals. They present strategies to each other and qualify the plans together. The workshop concludes with a session planning how to move on. In some cases this might include a research workshop where various experts or stakeholders from the outside are invited into the process as facilitators.

The FCW operates with rather rigid rules of equal participation to minimize negative effects of existing unequal power relations in the group. A workshop cannot overcome inequality, but it can create an environment where everybody is invited to take part, regardless of his or her social position in general. The aim is to create a "free space" -a laboratory of social imagination where we move from the perspective: How can we survive under current conditions? to the posing of a more basic question: How do we really want to live? Far too often, in our busy everyday life, we avoid such questions since they are too overwhelming to consider - let alone to answer.

Nevertheless, we need to keep the question alive in order to take democratic responsibility as participants in the development of local settings we take part in - and as participants in the broader societal democracy. The FCW provides for a simple but very effective framework. Often participants are surprised by the creativity evolving from the process. A diverse array of creative 
ideas and strategies emerge through the FCW. The inventor of the workshop, Jungk - hoped that the workshop method could support the revitalization of civil society after the totalitarian regimes in the Second World War. For years, the workshop spread and helped local communities to find and develop common interests in new bottom up organized ways (Nielsen and Nielsen, 2006, 2016). It is not unreasonable to suggest that CUAR might now be used to revitalize SE following its capture by neoliberal elements.

However, few articles actually use Action Research approaches with SE (a review by Granados 2011 identified six), although some papers do identify how / why action research might fit well' with the "complexities and inter-subjectivities" inherent in SE research (Tasker et al. 2010, p228.) since it can provide 'solid knowledge generation' and 'practical solutions to the problems identified' (250-251). Interestingly, three of these articles were published in this journal. Rotheroe and Richards (2007) adopted action research as a way of embedding accountability measures into a SE. McBrearty (2007), a consultant, reported on five 'action research' projects undertaken to assess feasibility of new SE business ideas. Ryan and Lynne (2008) draw upon studies they themselves conducted using SRIO methodologies, and describe the process as Action Research. It would seem there is a tendency for authors when describing their consultancy activities to label this as Action Research in order to fit the requirements of academic publishing. More relevant to the traditions of action research outlined in this article, Munoz et al. 2014 describe the processes of co-creating SEs in rural communities through a European union funded project: Older people for Older People. Gibbon and Affleck (2008) similarly describe the process of identifying problems, planning, acting and evaluating as part of a project encouraging SEs to adopt social accounting measures. But, even where such studies more closely approximate to the understanding of action research outlined in this paper, it is notable that the 'solution' identified - creating a SE, or social accounting, was predetermined before the action research process began. One wonders what creative solutions community members might come up with if given a truly blank slate from which to work with.

For example, an ongoing Danish Ph.D. project conducted by Astrid Kidde Larsen combines CUAR and SE approaches. Larsen explores how new public policies to engage civil 
society in the renewal and production of welfare services, can be implemented through strategies of co-creation and co-production. In her fieldwork based on CUAR methods, Larsen identifies how practitioners might influence such renewal strategies in democratic ways, drawing upon their own experiences, professional orientations and desires of improved welfare (Larsen and Larsgaard 2017; Larsen 2019). The preliminary results suggest that democratic rooting of the process inspires participants to stimulate creative ideas, but their realization requires considerable political support which is often not forthcoming.

\section{Concluding thoughts and a call to action}

In this article we have begun to outline the potential for fusing CUAR with SE scholarship. However, the task of the critical researcher is not to prescribe precisely what the reader should do. (see Dey and Steyaert, 2012). Instead we would leave the 'how' to those scholars whose curiosity and imagination is not bounded in the same ways as our own. However, to help stimulate an emancipatory agenda we hereby highlight two broad ways in which CUAR might work with SE.

First, CUAR researchers might work with community groups coming together around particular issues - the closure of village shops, the removal of a critical transport link may serve as examples. Future Creating Workshops in this sense would serve as a way of breaking from the idea of simply replacing the lost service, instead thinking in terms of what we would want in an ideal world. The subsequent task would be to articulate how a SE organizational response might be developed.

Second, CUAR researchers might work with existing SEs to help them reinvigorate their democratic potential, and to articulate what they are for. Much of the academic literature (and indeed our own example in the previous paragraph) presents $\mathrm{SE}$ as a replacement for something which is lost - market or state failure in academic parlance (Austin and Stevenson 2006; Defourny and Nyssens, 2006). It is likely that many SEs do indeed arise as a response to such failures. But this easily leads to a residual understanding whereby SE simply becomes a technical solution to the problems of the state or market (Dey and Steyaert, 2012). CUAR researchers might work with 
existing SEs to help them visualise their ideal world and articulate how they might work towards it, thus helping address the question: what is SE for?

In closing, we must be wary of overplaying the potential for CUAR to be applied to SE and change the world. CUAR approaches are time consuming and require openness towards unpredictable changes along the way. When used appropriately, practitioners have considerable say in defining the goals and methods. One may add, that production of knowledge and change in these praxis sensitive ways rarely provides a fast-track to academic tenure. Critical SE researchers remain but a few voices in an increasingly important field. Mainstream journals are notoriously resistant to new methodological approaches and / or articles which challenge the capitalist logics upon which they are founded. We are unlikely to get much help from research funders who, while opening up to interpretivist approaches, have not yet moved beyond the artificial separation of research and praxis. Moreover, even if we are able to conduct CUAR with SEs, it is unlikely that our academic papers will influence public policy since governments in many countries remain locked in hierarchies of evidence whereby randomised control trials are the gold standard we should aspire to (Cairney and Oliver, 2016). However, history has many times shown us, that change can come from below, and CUAR can at least encourage SEs and communities to conceptualise and begin to realise their visions(s) of an ideal world. As researchers (or indeed experts), we might relate to, and sympathise with, communities and SEs, while not always agreeing fully with their visions.

Nonetheless, perhaps it is our democratic duty to help articulate them?

\section{References}

Andersen, L. and Hulgård, L. (2016), 'Social Entrepreneurship: demolition of the Welfare State or an Arena for Solidarity?' in Andersen, L.L., Gawell, M. \& Spear, R. (Eds.), Social entrepreneurship and Social Enterprises: Nordic Perspectives, Routledge, New York, pp. $22-40$.

Becker-Schmidt, R (1982), 'Modsætningsfyldt realitet og ambivalens: kvinders arbejdserfaringer i fabrik og familie”, Udkast Dansk tidsskrift for kritisk samfundsvidenskab nr. 2 1982, 10. årg. pp. 164-198. 
Bidet, E. and Eum, H. S. (2011), 'Social enterprise in South Korea: History and diversity', Social Enterprise Journal, Vol. 7 No. 1, pp. 69-85.

Borzaga, G. \& Galera, G. (2013), 'Social Enterprise: A Neo-Liberal Strategy or a Participatory Model for Managing General-Interest Issues?', paper presented at $4^{\text {th }}$ EMES International Conference, July 2013, Liege, Belgium.

Cairney, P. and Oliver, K. (2017), 'Evidence-based policymaking is not like evidence-based medicine, so how far should you go to bridge the divide between evidence and policy?', Health research policy and systems, Vol. 15 No. 35.

Calò, F. and Teasdale, S. (2016), 'Governing the zoo', In Young, D., Searer, E. and Brewer, C. (eds.), The Social Enterprise Zoo: A Guide for Perplexed Scholars, Entrepreneurs, Philanthropists, Leaders, Investors, and Policymakers, Edward Elgar, Cheltenham UK, pp. 193-212.

Defourny, J. and Nyssens, M. (2014), 'The EMES Approach of Social Enterprise in a Comparative Perspective', in Defourny, J., Hulgård, L. and Pestoff, V. (eds.), Social Enterprise and the Third Sector - Changing European Landscapes in a Comparative Perspective, Routledge, New York, pp. 42-65.

Defourny, J., Hulgård, L. and Pestoff, V. (eds.) (2014), Social Enterprise and the Third SectorChanging European Landscapes in a Comparative Perspective, Routledge, New York.

Dey, P. and Steyaert, C. (2012), 'Social entrepreneurship: Critique and the radical enactment of the social', Social Enterprise Journal, Vol. 8 No.2, pp. 90-107.

Egmose, J. (2015), ‘A common sense of responsibility. Reflecting Experiences of Commoning among Citizens and Scientists in London', in Hansen, H-P., Nielsen, B.S., Sriskandarajah, N. and Gunnarsson, E. (eds.), Commons, Sustainability, Democratization: Action research and the basic renewal of society, Routledge, New York, pp. 248-262. 
Eikenberry, A. M. (2009), 'Refusing the market: A democratic discourse for voluntary and nonprofit organizations', Nonprofit and Voluntary Sector Quarterly, Vol. 38 No. 4, pp. 582-596.

Eikenberry, A. M. (2018), 'Social entrepreneurship and democracy', In Dey, P. and Steyaert, C. (eds.), Social Entrepreneurship: An Affirmative Critique, Edward Elgar, Cheltenham UK, pp. 210-229.

European Commission (2014), 'A map of social enterprises and their ecosystems in Europe. A report submitted by ICF Consulting Services', European Commission, Brussels.

European Commission (n.d.) "Social Enterprises", Commission and its priorities, n.d., http://ec.europa.eu/growth/sectors/social-economy/enterprises_en, website accesses 20.05.2019.

Galera, G. and Borzaga, C. (2009), 'Social enterprise: An international overview of its conceptual evolution and legal implementation', Social Enterprise Journal, Vol. 5 No. 3, pp. 210228.

Gibbon, J. and Affleck, A. (2008), 'Social enterprise resisting social accounting: reflecting on lived experiences', Social Enterprise Journal, Vol. 4, No. 1, pp.41-56.

Giddens, A. (1993), New rules of sociological method: A positive critique of interpretative sociologies, Polity Press, Cambridge.

Gleerup, J. (2010), Kritik og forandring. En anerkendelsesteoretisk analyse af social-og sundhedsmedarbejderes identitets- og meningsdannelse $i$ arbejdslivet. Roskilde: Forskerskolen i Livslang læring, Roskilde Universitet

Gleerup, J. and Nielsen, J. (2014), 'Skal vi ikke opfinde en rullende læringscafe', Dansk Pcedagogisk tidsskrift, Vol, 1, No. 14, pp. 18-30.

Granados, M.L., Hlupic, V., Coakes, E. and Mohamed, S. (2011), 'Social enterprise and social entrepreneurship research and theory: A bibliometric analysis from 1991 to 2010', Social Enterprise Journal, Vol. 7, No. 3, pp.198-218. 
Greenwood D. \& Levin, M. (2007), Introduction to Action Research: social research for social change, Thousand Oaks, Sage.

Hazenberg, R., Bajwa-Patel, M., Mazzei, M., Roy, M.J. and Baglioni, S. (2016), 'The role of institutional and stakeholder networks in shaping social enterprise ecosystems in Europe'. Social Enterprise Journal, Vol. 12, No. 3, pp.302-321.

Hulgård, L. (2015), 'Differing perspectives on civil society and the state', in Laville, J-L., Young, D. and Eynaud, P. (eds.), Civil Society, The Third Sector and Social Enterprise: Governance and Democracy, Routledge, New York, pp. 205-222.

Hulgård, L. (2014), 'Social enterprise and the third sector - innovative service delivery or a noncapitalist economy?', in Defourny, J., Hulgård, L. and Pestoff, V. (eds.) Social Enterprise and the Third Sector: Changing European Landscapes in a Comparative Perspective, Routledge, New York, pp. 66-85.

Hulgård, L. (2014), 'El futuro de la Socialdemocrazia', in Coraggio, J.L. and Laville, J-L. (eds.), Reinventar la izguierda en el siglo XXI, Clasco, Buenos Aires, pp. 355-371. Hulgard, L. and Shajahan, P.L. (2013), 'Social Innovation for People-Centred Development', in Moulaert, F., MacCallum, D., Mehmood, A. and Hamdouch, A. (eds.) 2013.The International Handbook on Social innovation: Collective action, Social learning and Transdisciplinary research, Edward Elgar, Cheltenham UK, pp. 93-106.

Hulgård, L. \& Spear, R. (2006), ‘Social Entrepreneurship and Mobilisation of Social Capital in European Social Enterprise', In Nyssens, M. (ed.), Social Enterprises: between Market, Public Policies and Community. Routledge, London UK, pp. 85-108. Hulgård, L. (2011), 'Social economy and social enterprise: an emerging alternative to mainstream market economy?', China Journal of Social Work. Vol. 4 No. 3, pp. 201-215. Jungk R. and Müllerts, N.R. (1984), Håndbog i Fremtidsvarksteder. Politisk Revy, København. Kay, A., Roy, M. J. and Donaldson, C. (2016), 'Re-imagining social enterprise', Social Enterprise Journal, Vol. 12 No. 2, pp. 217-234.

Kerlin, J. (2009), Social Enterprise: A Global Comparison, UNPE, Dartnouth. 
Larsen, A., and Larsgaard A . (2017), 'Samskabelse kræver noget andet - et studie af ligeværd i samskabelse', Tidsskrift for forskning og praksis $i$ socialt arbejde, 34/2017.

Larsen, A. (2018), 'Hvad er meningen med samskabelse? En empirisk funderet analyse', Dansk Pcedagogisk Tidsskrift, 4/2018.

Laville, J-L., Young, D., and Eynaud,P. eds. (2015), Civil society, the third sector and social enterprise: Governance and democracy. Routledge, London.

McBrearty, S. (2007), 'Social enterprise: a solution for the voluntary sector?', Social Enterprise Journal, Vol. 3, No. 1, pp.67-77.

Moulaert, F., Jessop, B. Hulgård, L. and Hamdouch, A. (2013), 'Social Innovation: A new stage in innovation process analysis?' in Moulaert, F., MacCallum, D., Mehmood, A. and Hamdouch, A. (eds.) 2013.The International Handbook on Social innovation: Collective action, Social learning and Transdisciplinary research, Edward Elgar, Cheltenham UK, pp. 110-130.

Munoz, S.A., Steiner, A. and Farmer, J. (2014), 'Processes of community-led social enterprise development: learning from the rural context', Community Development Journal, Vol. 50, No. 3, pp.478-493.

Negt, O. (1985), Det levende arbejde den stjålne tid. De politiske sider af kampen for nedsat arbejdstid, Politisk Revy, København.

Negt, O. (1994), "Hvad skal en arbejder vide for at finde sig til rette i verden i dag?" in Nielsen, Larsen, Olesen, Weber (eds.), Arbejde og subjektivitet - en antologi om arbejde, køn og erfaring. Erhvervs- og voksenuddannelsesgruppen. Roskilde Universitet.

Nielsen, K.A. and Nielsen, B.S. (2005), 'Kritisk-utopisk aktionsforskning' in Jensen, T and Christensen, G. (eds.), Psykologiske \& paedagogiske metoder, Roskilde Universitetsforlag, Frederiksberg DK, pp. 155-180.

Nielsen, KA \& Nielsen, BS (2006), 'Methodologies in Action Research' in Nielsen, K.A. and Svensson, L. (eds.), Action Research and Interactive Research. Beyond Practice and Theory, Shaker Publishing, Maastricht NL, pp. 63-88. 
Nielsen, B. S. and Nielsen, K.A. (2016), 'Critical Utopian Action Research. The Potentials of Action Research in Democratization of Society', in Hansen, H-P., Nielsen, B.S., Sriskandarajah, N. and Gunnarsson, E. (eds.), Commons, Sustainability, Democratization: Action research and the basic renewal of society, Routledge, New York, pp. 74-106.

Nyssens, M. (ed.), (2006), Social Enterprises: between Market, Public Policies and Community. Routledge, London UK.

Nyssens, M. and Petrella, F. (2013), 'From common goods to quasi-collective goods: the role of multi-stakeholder ownership', paper presented at $4^{\text {th }}$ EMES International Conference, July 2013, Liege, Belgium.

Perren, L. (2018), 'Social entrepreneurship: mythological doublethink', In Dey, P. and Steyaert, C. (eds.), Social Entrepreneurship: An Affirmative Critique, Edward Elgar, Cheltenham UK, pp. 127-136.

Pestoff, V. (2014), 'The role of Participatory Governance in the EMES Approach to Social Enterprise', Journal of Entrepreneurial and Organizational Diversity, Vol. 2 No.2, pp. $48-60$.

Pestoff, V. and Hulgård, L. (2016), 'Participatory Governance in Social Enterprise', Voluntas: International Journal of Voluntary and Nonprofit Organization, Vol. 27 No. 4, pp. 1742-1759.

Prodi, R. (2002), “Co-operative added value”, The European Co-operative Convention. Brussels: EU-Commission, Speech 02/66

Reason, P. and Bradbury, H. (eds.), (2006), The Handbook of Action Research, Second Edition, Sage, London UK.

Rotheroe, N. and Richards, A. (2007), 'Social return on investment and social enterprise: transparent accountability for sustainable development', Social Enterprise Journal, Vol. 3, No. 1, pp.31-48. 
Ruebottom, T. (2018), 'Deliberative democracy in social entrepreneurship: a discourse ethics approach to participative processes of social change', In Dey, P. and Steyaert, C. (eds.), Social Entrepreneurship: An Affirmative Critique, Edward Elgar, Cheltenham UK, pp. 191-209.

Ryan, P.W. and Lyne, I. (2008), 'Social enterprise and the measurement of social value: methodological issues with the calculation and application of the social return on investment', Education, Knowledge \& Economy, Vol. 2, No. 3, pp.223-237.

Skjervheim, H. (1996), 'Participant and spectator' in Selected essays, in honour of Hans Skjervheim's $70^{\text {th }}$ birthday. Department of Philosophy Bergen.

Smith, G. and Teasdale, S. (2012), 'Associative democracy and the social economy: exploring the regulatory challenge', Economy and Society, Vol. 41 No. 2, pp. 151-176.

Steiner, A. and Teasdale, S. (2016), 'The playground of the rich? Growing social business in the 21st century', Social Enterprise Journal, Vol. 12 No.2, pp. 201-216.

Tasker, M., Westberg, L., \& Seymour, R. G. (2010), 'Action Research in Social Entrepreneurship: A Framework for Involvement. International Journal of Action Research', Vol. 6, No. $2-3,223-255$.

Teasdale, S. (2012), What's in a name? Making sense of social enterprise discourses, Public Policy and Administration, Vol. 27, No. 2, pp. 99-119.

Weber, K., Nielsen, B.S and Olesen, H.S. (1997), Modet til fremtiden-inspirationen fra Negt, Roskilde Universitetsforlag, Roskilde.

Young, D. R. and Kim, C. (2015), 'Can social enterprises remain sustainable and mission-focused? Applying resiliency theory', Social Enterprise Journal, Vol. 11 No. 3, pp. 233-259. 